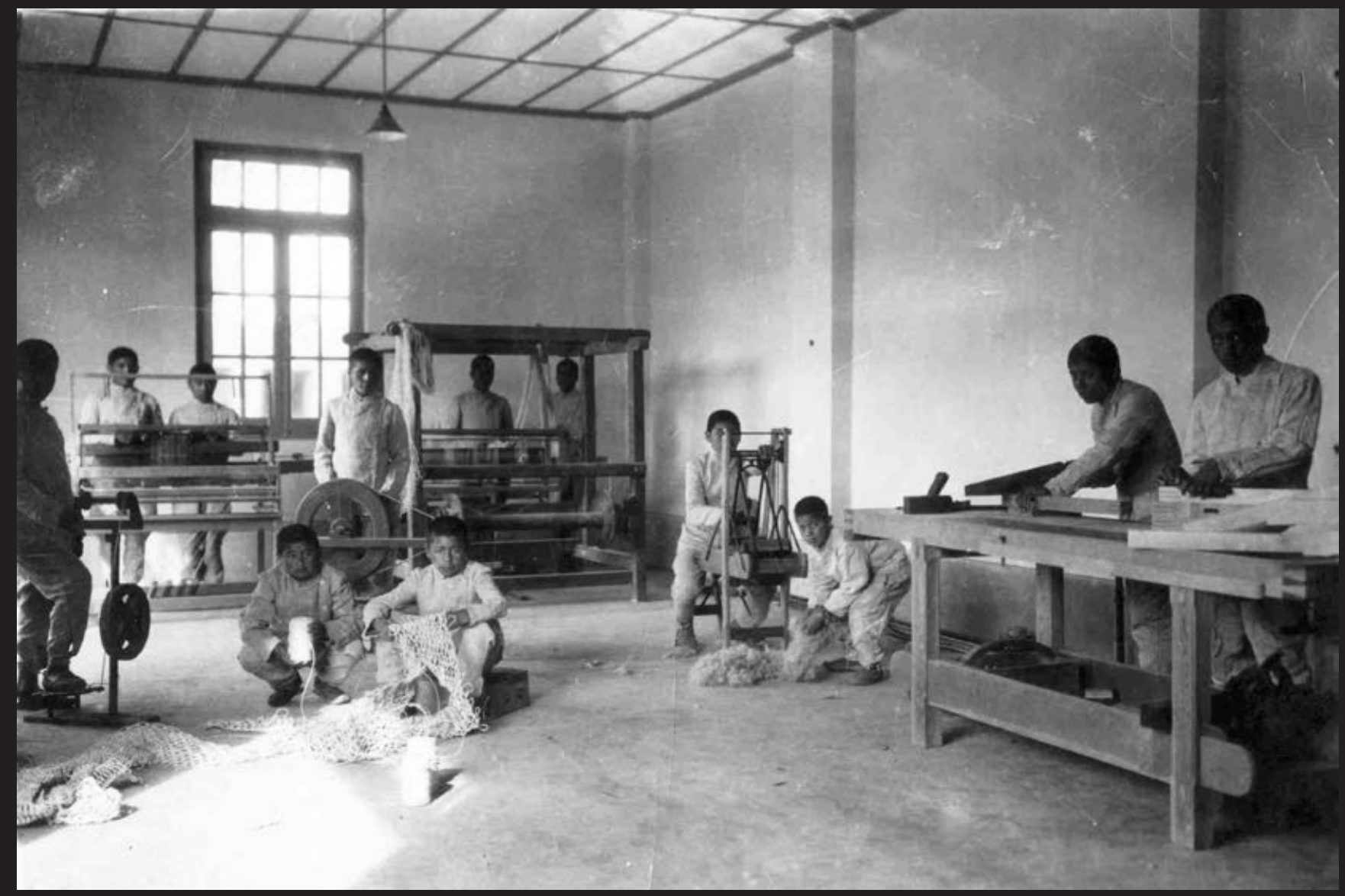




\section{La construcción visual de la nación y sus otros. Imágenes y alteridades en la Patagonia argentina}

The visual construction of the nation and its others. Images and otherness in the Argentine Patagonia A construção visual da nação e seus outros. Imagens e alteridades na Patagônia argentina

Fernando M. Sánchez

Universidad Nacional del Comahue (Neuquén, Argentina)

efesanchez@yahoo.com.ar
Artículo de investigación.

\section{Resumen}

En el contexto de constitución del Estado argentino a fines del siglo XIX, las campañas militares de extensión de fronteras fueron acompañadas por una abundante elaboración cartográfica de los nuevos espacios y una práctica etnográfica de apropiación de la vida de las poblaciones nativas, que derivó en la conformación de colecciones de fotografías, cráneos y esqueletos, así como en la exhibición de grupos de nativos vivos en museos. El presente trabajo aborda los procesos de producción simbólica y efectiva de la nación y sus otros internos. A partir del análisis de registros fotográficos documentales de la llamada Conquista del Desierto, y de una serie de fotografías producidas por las propias organizaciones mapuche durante las últimas décadas, en tiempos de reafirmación cultural, se intenta dar cuenta de los cambios en las políticas de representación visual, así como de su imbricación en disputas político-culturales más amplias.

\section{Palabras clave}

alteridad; construcción visual; imaginario; indígenas; Estado nación; desierto

\section{Abstract}

In the context of the constitution of the Argentine State at the end of the 19th century, the military campaigns of border extension were accompanied by an abundant cartographic elaboration of the new spaces and an ethnographic practice of appropriation of the life of the native populations. This resulted in the formation of collections of photographs, skulls, and skeletons, as well as in the exhibition of groups of living natives in museums. This work approaches the symbolic and effective production processes of the nation and its other internal ones. Based on the analysis of documentary photographic records of the so-called Conquest of the Desert, and of a series of photographs produced by the Mapuche organizations themselves during the last decades in times of cultural reaffirmation, we make an attempt to account for the changes in visual representation policies, as well as in how it is interweaved in broader political-cultural disputes.

\section{Resumo}

No contexto de constituição do Estado argentino no final do século XIX, as campanhas militares de extensão de limites foram acompanhadas por abundante elaboração cartográfica dos novos espaços e uma prática etnográfica de apropriação da vida das populações nativas, que derivou na conformação de coleções de fotografias, caveiras e esqueletos, bem como na exibição de grupos de nativos vivos em museus. $\mathrm{O}$ presente trabalho aborda os processos de produção simbólica e efetiva da nação e seus outros internos. A partir da análise de registros fotográficos documentais da chamada de Conquista do Deserto, e de uma série de fotografias produzidas pelas próprias organizações mapuche durante as últimas décadas, em tempos de reafirmação cultural, visa-se dar conta das mudanças nas políticas de representação visual, bem como da sua imbricação em disputas político-culturais mais amplias.

\section{Keywords}

otherness; visual construction; imaginary; indigenous peoples; Nation state; desert

\section{Palavras-chave}

alteridade; construção visual; imaginário; indígenas; Estado nação; deserto

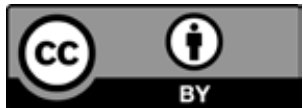

/ Mem.soc / Bogotá (Colombia) / ISSN 0122-5197 (impreso) - ISSN 2248-6992 (en línea) / 21 (43): 86-103 / julio-diciembre de 2017 / 87 


\section{Introducción}

El advenimiento de la modernidad trajo aparejado un nuevo modo de organización social, política, económica y epistémica, pero también un modo de administración de la diversidad cultural, a partir de la instalación de ciertas pautas particulares como criterio de valoración, negando o relegando los saberes y modos de existencia diferentes, calificados como error, superstición, desviación, atraso y otros rótulos similares.

En este sentido, Castro-Gómez caracteriza la conformación del sistema mundo moderno colonial ${ }^{1}$ como una política de universalización de valores occidentales, a la vez que como una máquina de producir alteridades subordinadas; de esta manera la «invención del otro» se convirtió, a partir del proceso de expansión ultramarina europea, en una vía de convalidación de su imposición cultural, política, económica y militar.

Un proceso similar tuvo lugar al nivel de los estados nacionales, con la implementación de regímenes disciplinarios y reguladores tendientes a conformar ciudadanías integradas y ordenadas. ${ }^{2}$ En este sentido, siguiendo el enfoque foucaultiano, el autor analiza el funcionamiento de una «doble gubernamentalidad» gravitando sobre el eje del Estado nación: fronteras adentro en la conformación de la ciudadanía con determinados perfiles de subjetividad, y fronteras afuera en la relación asimétrica, en términos de centro y periferias, entre las metrópolis coloniales y los pueblos y naciones no

1 El concepto de «sistema-mundo moderno/colonial» fue acuñado por Walter Mignolo, y es retomado por Castro-Gómez como parte de su análisis de la conformación interrelacionada, a nivel geopolítico, de centro y periferias, civilización y salvajismo, desarrollo y atraso, etc. En esa línea, cuestiona los discursos que enfatizan el progreso occidental como si fuera resultado de «cualidades inherentes», invisibilizando el papel desempeñado por las relaciones coloniales. Santiago Castro-Gómez, «Ciencias Sociales, violencia epistémica y el problema de la "invención del otro"», en La colonialidad del saber: etnocentrismo y ciencias sociales, comp. Edgardo Lander (Caracas: CLACSO, 2000), 152.

2 El análisis de la sociedad moderna en cuanto «sociedad de normalización» es efectuado por Michel Foucault en diversos trabajos, uno de ellos es Defender la Sociedad. Curso 1975-1976 (Buenos Aires: FCE, 2010). occidentales. ${ }^{3}$ Una instancia fundamental de escenificación del discurso de la superioridad cultural de occidente y de su legitimidad para conducir a los pueblos extraeuropeos en el camino de la civilización, fueron las exposiciones universales desarrolladas sistemáticamente por las metrópolis durante la segunda mitad del siglo XIX y primera parte del XX. ${ }^{4}$

La organización de espacios de exhibición de cuerpos y objetos, así como la difusión de la técnica fotográfica, fueron factores importantes en el desarrollo del nuevo régimen de visibilidad en ciernes. Bennett ${ }^{5}$ considera la instalación de lo que denomina «complejo exhibicionario", como un dispositivo fundamental en la economía de poder de los estados europeos, ya que implicó la puesta en acto de un relato acerca de las diferencias dirigido a legitimar las relaciones de desigualdad y dominación inherentes a la política colonial.

Museos, galerías y exposiciones que se multiplicaron durante el siglo XIX cumplieron un papel importante en la formación de una pretendida cohesión e identidad nacionales, fomentando el aprendizaje simultáneo sobre sí mismos y sobre los otros. Fueron, en términos de Bennett, «un conjunto de agencias educativas y civilizadoras», ${ }^{6}$ importantes en tanto tecnologías culturales tendientes a la integración de una ciudadanía que se sintiera partícipe del proceso de modernización en marcha.

La fotografía adquirió en este periodo gran importancia, tanto en el viejo como en el nuevo mundo. La posibilidad de reproducción técnica de imágenes permitió la extensión del relato visual de las diferencias más allá del lugar y momento puntual de las exhibiciones, a través de tarjetas postales, periódicos, revistas y libros. De este modo, las políticas estatales de difusión de

\footnotetext{
3 Castro-Gómez, «Ciencias Sociales, violencia epistémica», 154.

4 La articulación entre geopolítica colonial, saberes científicos y prácticas de exhibición zooantropológica es abordada en Fernando Sánchez, «Inventarios de la civilización. Geopolíticas del saber y exhibiciones zooantropológicas en la construcción del mundo moderno colonial», Revista Chilena de Antropología Visual, n. 22 (2013): 46-67.

5 Tony Bennett, «The Exhibitionary Complex», en The Birth of the Museum. History, Theory, Politics, ed. Tony Bennett (Routledge: London, 1995).

6 Bennett, «The Exhibitionary Complex», 79.
} 
sus proyectos civilizatorios incluyeron «el uso de la imagen como registro incontrovertible del progreso», ${ }^{7}$ que sería resaltado a través de la visualización, como a contraluz, de los modos de vida de los pueblos conquistados.

Pero también tuvo una notable utilidad en el ámbito científico, como técnica de apoyo de la investigación antropológica. La fotografía fue una herramienta importante en la construcción del saber acerca de los otros, especialmente en los estudios raciales comparativos de gran auge en la época. Su mérito fue ofrecerse como prueba, dada la aparente identidad de la imagen fotográfica con lo real, a la vez que posibilitar la fijación (para el archivo y para la circulación entre quienes lo requirieran) de aquello que se dio a ver de manera directa y momentánea solo a algunos. ${ }^{8}$

Para esta misma época, la investigación antropológica en Latinoamérica, y en particular en Argentina, siguió un enfoque muy similar. En el contexto de constitución del estado argentino, la política de extensión de fronteras fue acompañada por una práctica etnográfica de apropiación de la vida de las poblaciones nativas, que se plasmó en la conformación de colecciones de fotografías, cráneos y esqueletos, así como también de «nativos vivos» que pasaron a engrosar los recintos de algunos importantes museos, especialmente el de Ciencias Naturales de La Plata, bajo la dirección de Francisco Moreno.

El material fotográfico sobre la población indígena sometida, tanto en el norte como en el sur del país, es actualmente un importante acervo documental que permite indagar sobre el modo de incorporación de los pueblos originarios a la estructura del Estado nación, a la vez que conocer la concepción dominante acerca

7 Marta Penhos, «Frente y perfil. Una indagación acerca de la fotografía en las prácticas antropológicas y criminológicas en Argentina a fines del siglo XIX y principios del XX», en Arte y Antropología en Argentina (Buenos Aires: Fundación Espigas, 2005), 21.

8 Un trabajo de sistematización sobre la relación entre fotografía y antropología puede verse en Juan Naranjo, Fotografía, antropología y colonialismo (1845-2006) (Barcelona: Editorial Gustavo Gili, 2006). Véase también Christian Báez y Peter Mason, Zoológicos humanos. Fotografías de fueguinos y mapuche en el Jardin d'Acclimatation de París, siglo XIX (Santiago de Chile: Pehuén Editora, 2006). de las diferencias culturales y raciales durante el último tramo del siglo XIX y buena parte del siglo XX.

En este sentido resulta interesante observar el desarrollo simultáneo de las campañas militares de ocupación de nuevos territorios, la construcción de un imaginario de nación blanco-europea, y la estigmatización de las poblaciones nativas preexistentes, identificadas con el atraso y consideradas un obstáculo para el progreso. Dentro del régimen general de enunciación y visualización de los otros, el registro fotográfico y fílmico no solo vino a complementar el registro etnográfico tradicional, sino que produjo un giro importantísimo en la producción y difusión de un imaginario particular acerca de las diferencias.

Este trabajo propone un abordaje de la producción y representación de la alteridad en Argentina articulando tres niveles de análisis: el proceso histórico de constitución del Estado nación y la incorporación militar-cultural de los pueblos nativos; la conformación de un imaginario acerca del desierto, con base en la dicotomía civilización-barbarie; y tendiendo un puente con el presente, la posibilidad de creación de nuevos relatos visuales de la nación y sus otros, remitiendo a la experiencia reciente de montaje de la muestra fotográfica «De la conquista a la afirmación del pueblo mapuche». ${ }^{9}$

\section{Políticas territoriales y culturales. La nación y sus otros}

La conformación de los estados nacionales latinoamericanos, y del argentino en particular, incluyó operaciones de desambiguación, tanto en relación a los límites geográficos como a las

9 La muestra formó parte de un proyecto de extensión universitaria (U. N. del Comahue) y se realizó en colaboración con la Confederación Mapuche de Neuquén. Durante los años 2016 y 2017 circuló por distintos asentamientos de la Universidad y diversos institutos de formación docente de la región. Conjuntamente con su exhibición se llevaron a cabo charlas abiertas al público abordando el proceso de ocupación territorial de norpatagonia en el siglo XIX y sus derivaciones hasta el presente, así como el análisis de los diferentes modos de construcción visual de la alteridad y su interrelación con los respectivos contextos históricos, políticos y epistémicos.

La construcción visual de la nación y sus otros. Imágenes y alteridades en la Patagonia argentina / Fernando M. Sánchez / 89 
pertenencias socioculturales de diversos grupos humanos; en este sentido puede hablarse de políticas de conformación de ciudadanía, en nombre de una pretendida identidad nacional.

De este modo, el conflictivo proceso de unificación política y territorial del país, que atravesó gran parte del siglo XIX y extendió sus efectos aún al siglo $\mathrm{XX}$, se desarrolló conjuntamente con una política de unificación cultural, cuya consecuencia más directa fue la implementación de programas de eliminación o sometimiento de la diversidad étnico-racial existente. Esta estrategia de administración de la diversidad es conceptualizada por Briones como una construcción hegemónica de «geografías estatales de inclusión y exclusión», en la que «la Nación-como-Estado opera como territorio simbólico contra el cual se recortan y en el cual circulan distintos tipos de "otros internos"». ${ }^{10}$

La organización del Estado nacional incluyó, de este modo, operaciones de territorialización signadas por la violencia, sobre amplios espacios hacia el norte y el sur de la pampa bonaerense históricamente habitados por diversos pueblos originarios. Como señala Lois en la segunda mitad del siglo XIX se llevó a cabo «un conjunto de políticas territoriales e institucionales orientadas a definir y consolidar el territorio estatal. Probablemente, las acciones más rotundas realizadas en ese sentido fueron las avanzadas militares sobre los territorios indígenas del Chaco y de la Patagonia». ${ }^{11}$

La expansión de fronteras que anexó importantes extensiones de tierra al erario público, significó también la desarticulación de las comunidades indígenas y sus modos de vida, que en muchos casos fueron reducidas o dispersadas en distintos puntos del país. Un proceso similar tuvo lugar a ambos lados de la cordillera durante el proceso de conformación estatal de

10 Claudia Briones, «Formaciones de alteridad: contextos globales, procesos nacionales y provinciales», en Cartografías argentinas. Políticas indigenistas y formaciones provinciales de alteridad, ed. Claudia Briones (Buenos Aires: Antropofagia, 2005), 23.

11 Carla Lois, «Técnica, política y deseo territorial en la cartografía oficial de la Argentina (1852-1941)», Scripta nova. Revista electrónica de geografía y ciencias sociales X, n. ${ }^{\circ} 218$ (2006).
Argentina y Chile. ${ }^{12}$ En ambos casos se trató de un avance sobre el pueblo mapuche, preexistente al establecimiento de la cordillera de los Andes (lugar de circulación ancestral) como frontera internacional, hecho que ocasionó la división e incorporación de este pueblo en dos estados diferentes.

En el caso argentino, las campañas militares de expansión de fronteras fueron episodios centrales de un proyecto civilizatorio: conquistar el desierto significaba a la vez garantizar el triunfo del progreso y la cultura sobre la barbarie. La figuración de la pampa y la estepa patagónica como desierto implicaba una idea de vacío, más pensado en términos culturales que materiales; un espacio habitado por poblaciones sin valor, juicio que se traducía en muchos discursos de la época en la propuesta explícita del exterminio como solución del «problema indígena». Esa construcción simbólica del desierto a ocupar se vio reafirmada por una profusa literatura, y de manera muy especial por el uso de la fotografía. ${ }^{13}$

Posteriormente a las campañas militares, entre fines de siglo XIX y las primeras décadas del XX, se aplicó sobre la población nativa superviviente un conjunto de políticas asimilacionistas tendientes a la eliminación de sus particularidades culturales. La integración al «cuerpo de la nación» de poblaciones con historias, valores, cosmovisiones y prácticas culturales diversas se efectuó según un criterio de ciudadanía que requería la renuncia a los

12 La «Campaña al Desierto» desarrollada por el Estado argentino (1879-1885) tuvo su equivalente del lado chileno con la denominada «Pacificación de la Araucanía» (1861-1883).

13 Este punto es específicamente analizado en Héctor Alimonda y Juan Ferguson, «La producción del desierto. Las imágenes de la campaña del Ejército Argentino contra los indios, 1879», Revista Chilena de Antropología Visual, n. ${ }^{\circ} 4$ (2004). http://www.antropologiavisual.cl/alimonda_\&_ferguson.htm; Verónica Tell, «La Toma del Desierto. Sobre la auto-referencialidad fotográfica», en Actas del I Congreso Internacional de Teoría e Historia de las Artes/IX Jornadas del CAIA «Poderes de la Imagen», Buenos Aires, CAIA, 2003 (CD-ROM); Ines Yujnovsky, «La conquista visual del país de los araucanos (1879-1881)», Takwá, n. ${ }^{\circ} 14$ (2008). http://www.publicaciones.cucsh.udg.mx/pperiod/takwa/ volumenes/tak14.htm; y Julio Risso, «Estado Nación, Conquista del Desierto e imágenes de(I) nos-otros. Una propuesta de lectura sobre (re)presentaciones identitarias en Argentina», Jornadas Internacionales de Problemas Latinoamericanos, Universidad Nacional de Cuyo, Mendoza, Argentina, 2012, entre otros. 
horizontes de pertenencia previos, a la vez que la adopción del estatus de ciudadanos argentinos, que, paradójicamente, nunca les sería reconocido plenamente. En este sentido puede hablarse de un proceso de ocupación territorial pero también cultural y simbólica de los espacios incorporados a la Nación. En síntesis, podemos caracterizar el proceso de unificación territorial, idiomática y cultural del Estado argentino, como un modo de administración de la multiplicidad étnica preexistente, que osciló entre el exterminio, el desplazamiento y la reducción, primero, y la incorporación subordinada, después, en lógicas e instituciones estatales, occidentales y capitalistas.

Una de las piezas claves de las políticas asimilacionistas postconquista fue el sistema educativo, prontamente instalado en los territorios incorporados a la jurisdicción nacional. En la zona limítrofe con Chile se implementaron escuelas de frontera, y en el resto del territorio una serie de escuelas rurales destinadas a la población criolla e indígena, con una clara finalidad alfabetizadora a la vez que nacionalizadora. Un caso especialmente relevante para este análisis es la creación en la década de 1930, en la ciudad de Neuquén (capital del entonces Territorio Nacional del Neuquén), ${ }^{14}$ de una escuela destinada exclusivamente a niños indígenas. ${ }^{15}$ Se trataba de la Escuela Granja Hogar Ceferino Namuncurá, entre cuyos fundamentos estaba ocuparse de «la instrucción general de la niñez indígena del Territorio», teniendo como especial objetivo «enseñarles un oficio o profesión para que al egresar de ella, vuelvan a sus antiguos hogares educados y capacitados para, no sólo servirse a sí mismos, sino para orientar a los demás e infiltrarles, por reacción

14 Los espacios anexados con las campañas militares fueron incorporados al mapa nacional con la figura de Territorios Nacionales; jurisdicciones geográfico-administrativas dependientes directamente del Estado central. En el caso del Neuquén y otros cinco territorios en que se dividió la Patagonia, fue creado por la Ley 1532 en 1884.

15 Las características y el funcionamiento de esta institución fueron tratadas específicamente en Fernando Sánchez, «El Internado para niños indígenas Ceferino Namuncurá. Un caso paradigmático de educación asimilacionista», en Construcción de espacios interculturales, comp. Raúl Díaz y Graciela Alonso (Buenos Aires - Madrid: Ed. Miño y Dávila, 2004). natural, mejores normas de vida, haciendo desaparecer la inercia y despreocupación que hoy les domina». ${ }^{16}$

Este modo de tratamiento de la diversidad étnico-cultural se mantuvo en líneas generales durante la mayor parte del siglo XX, en consonancia con una tendencia similar en toda Latinoamérica. Solo a partir de las últimas décadas del siglo comenzó a ser audible para la sociedad y las instituciones estatales un discurso diferente, que planteaba el reconocimiento de la diversidad, poniendo en cuestión la concepción etnocéntrica y jerarquizante dominante hasta entonces.

A partir de la conmemoración del Quinto Centenario en 1992, se dio una importante activación de movimientos indígenas en distintos lugares de América. En el contexto norpatagónico se produjo una irrupción de las organizaciones mapuche en la esfera pública, irrupción caracterizada por la autoafirmación identitaria y una serie de reclamos político-culturales. Con base en la afirmación como Pueblo $\mathrm{Na}^{-}$ ción Mapuche, denunciaban el sesgo paternalista y represivo de las tradicionales políticas indigenistas estatales.

La presentación de una bandera consensuada entre las diversas comunidades de la región y la reivindicación del idioma propio ${ }^{17}$ fueron elementos importantes en el proceso de auto-reconocimiento como un único pueblo extendido a ambos lados de la cordillera, preexistente a las estructuras estatales. La afirmación de la identidad cultural junto con la reivindicación de territorio y autonomía como derechos fundamentales, conformaron el eje del discurso político de las organizaciones mapuche, en concordancia con la tendencia mundial de reconocimiento de derechos a los pueblos indígenas y tribales. ${ }^{18}$

16 «Nota-informe del Señor Maestro D. Edmundo Betelu, encargado dirección Escuela "Granja-Hogar Indígena Ceferino Namuncurá", respecto al funcionamiento de la misma durante el curso del año 1939 y resultados obtenidos», en Gobernación del Neuquén. Memoria Año 1939. Sistema Provincial de Archivos, Prov. de Neuquén, Argentina.

17 Mapudugun, o lengua de la tierra, en consonancia con su autodenominación como mapuche, gente de la tierra.

18 El convenio 169 de la OIT (1989) fue un hito importante al que siguieron otros instrumentos normativos internacionales y

La construcción visual de la nación y sus otros. Imágenes y alteridades en la Patagonia argentina / Fernando M. Sánchez / 91 
Pese a los avances conseguidos a fuerza de luchas y presencia pública en tanto pueblo y cultura viva, y pese al reconocimiento de amplios sectores y organizaciones sociales, los problemas derivados del despojo territorial iniciado en el siglo XIX siguen siendo graves. En los últimos años, el incremento de actividades económicas extractivas en territorio de las comunidades, al igual que la presión de emprendimientos turísticos y desarrollos inmobiliarios, han sido obstáculos importantes para implementar lo que denominan Kume Felen («buen vivir»), de acuerdo a modos de organización, valores y prácticas propias.

\section{Acerca de la fotografía y la construcción de alteridades}

Como se mencionó anteriormente, la producción visual tiene un lugar importante, desde hace alrededor de un siglo, en la conformación de imaginarios acerca de nosotros y los otros, que en muchos casos muestra, prefigura y legitima relaciones de dominación. En el caso aquí abordado, resulta interesante el análisis de los modos históricos de representación visual de las fuerzas de la nación (que buscaron siempre equipararse —en una operación hegemónica de construcción de ciudadanía- con un nosotros mayoritario) y, paralelamente, las imágenes de los otros, sobre quienes no solo cabía guardar distancia sino llevar a cabo estrategias tendientes a gobernarlos o eliminarlos física y culturalmente.

Uno de los rendimientos de las imágenes técnicas en relación con la construcción de relatos con efecto de verdad, es su «carácter fuertemente persuasivo", ${ }^{19}$ basado en un halo de objetividad, de aparente transparencia, que tiende a ocultar - con mayor o menor éxito según los casos- operaciones de puesta en escena, encuadre, selección de escenarios y objetos, montaje, sobreimpresiones textuales y

nacionales orientados a garantizar los derechos de los pueblos originarios. En 1994, con la reforma de la Constitución nacional argentina se incorporó en la carta magna el reconocimiento de su prexistencia étnica respecto del Estado.

19 Penhos, «Frente y perfil», 18 otros recursos que forman parte de la producción fotográfica. Se puede observar en este caso - retomando el concepto de «invención del otro» de Castro-Gómez (2000) - la invención fotográfica del otro, a modo de contraluz y legitimación de los intereses del proyecto civilizatorio en marcha. ${ }^{20}$

A diferencia del retrato en la fotografía social burguesa, los sujetos fotografiados en función de intereses científicos, políticos o misionales, no se daban a conocer, sino que eran compulsivamente entregados a la mirada. ${ }^{21}$ En un sentido similar puede afirmarse que la fotografía etnográfica, dentro de las relaciones asimétricas de poder en que tradicionalmente se realizó, producía un efecto de inferiorización de los sujetos retratados, una especie de segunda subordinación, en el plano de la representación.

Lo fotográfico se instala en el centro de un dispositivo general de disciplinamiento y centralización de la información sobre los sujetos, pero constituye también una máquina de escribir sobre los cuerpos, de producir subjetividades, de preservar cuerpos para el recuerdo, de identificar otros para diseccionarlos del cuerpo social como elementos anómalos y enfermos. ${ }^{22}$

La tecnología visual no solo es un modo de captura de imágenes de cuerpos o rostros, sino que

20 Un análisis en esta línea puede verse en Mariana Giordano, «Nación e identidad en los imaginarios visuales de la Argentina. Siglos XIX y XX», ARBOR Ciencia, Pensamiento y Cultura, n. ${ }^{\circ} 740$ (2009). Para el contexto chileno: Margarita Alvarado, Pedro Mege Rosso y Christian Báez Allende, Mapuche: fotografías siglos XIX y $X X$. Construcción y montaje de un imaginario (Santiago de Chile: Pehuén Editores, 2001).

21 En relación a las fotografías etnográficas producidas durante la campaña científica de Lehmann-Nitsche a principios del siglo XX, en la que retrató a indígenas en el ingenio azucarero La Esperanza (Provincia de Jujuy, República Argentina), Alejandro Martínez y Liliana Tamagno en «La naturalización de la violencia: Un análisis de fotografías antropométricas de principios del siglo $X X$ », Cuadernos de Antropología Social, n. 24 (2006): 93-112, señalan que resulta imposible «mirar e interpretar esas fotografías sin pensar en la violencia presente en las relaciones que las hicieron posibles». Se trata de varias decenas de fotografías de frente y perfil, mayormente desnudos, tomadas a mujeres y hombres wichí trabajadores de la zafra, cuya realización fue posibilitada por la intervención del dueño del ingenio y de la policía local. Las fotografías en cuestión, más el registro de una interesante experiencia de devolución de esas capturas fotográficas a las comunidades (probablemente a los descendientes) en las que les fueron tomadas, se encuentra en Xavier Kriscautzky, Desmemoria de la Esperanza (Buenos Aires: Ministerio de Educación de la Nación, 2007).

22 Paula Cortés Rocca, El tiempo de la máquina. Retratos, paisajes y otras imágenes de la nación (Buenos Aires: Ed. Colihue, 2011), 70. 
define y transforma a los sujetos que posan frente a la cámara. En este sentido puede afirmarse que el acto fotográfico y la circulación de imágenes implican también modos de subjetivación. Lejos de ser el reflejo de una realidad existente, es un modo de producción visual de realidades.

Siguiendo el planteo de Barthes en La cámara lúcida ${ }^{23}$ los registros fotográficos constituyen documentos de lo que ha sido; en cierto modo permiten presentificar hechos pasados, aunque nunca logran completar esa operación de manera limpia, en tanto se muestran a la mirada en el presente, $y$ desde el presente son pasibles de reinterpretación. Por esta razón, la fotografía histórica puede convertirse en un objeto para la reflexión crítica: de lo que esas mismas imágenes muestran, de sus modos de composición y de los sentidos que originalmente se buscaron producir y consolidar socialmente. Más aún, se puede pensar los procesos de representación como la interrelación entre producción de imágenes, políticas de la memoria y disputas de sentido.

La tarea de resignificación de imágenes documentales de amplia difusión, así como la posibilidad de producción de nuevos relatos visuales acerca de las diferencias, fue el interés central del proyecto de extensión «Imágenes y Alteridades». ${ }^{24}$ Una de las actividades que llevamos a cabo en ese marco fue la selección y composición de una serie de fotografías con el fin de elaborar un recorrido visual por los últimos 130 años de estrategias de ocupación y disputas en el espacio norpatagónico. El resultado fue la producción de la muestra fotográfica «De la conquista a la afirmación del Pueblo mapuche». La muestra, compuesta de 45 fotografías -algunas de las cuales se incluyen en el anexo-, fue organizada en tres secciones correspondientes a tres etapas temporales. La primera parte corresponde a la llamada Conquista del Desierto. Se trata de una selección

23 Roland Barthes, La cámara lúcida. Nota sobre la fotografía (Barcelona: Paidós, 1989).

24 Proyecto «Imágenes y alteridades. Relevamiento, análisis y producción de registros visuales de la multiplicidad», Secretaría de Extensión Facultad de Humanidades, Universidad Nacional del Comahue, Neuquén, Argentina. Periodo 2015-2016. dentro del amplio corpus fotográfico de carácter documental producido por Pozzo en 1879, y por Moreno y Encina unos años después. Estos fotógrafos marcharon con sus equipos junto a las columnas del Ejército expedicionario, formando parte de la maquinaria de conquista de territorios y de hombres, al igual que topógrafos, ingenieros y sacerdotes. ${ }^{25}$

La segunda parte corresponde a la época postconquista. Se trata de fotografías de la primera mitad del siglo XX tomadas en el Territorio Nacional del Neuquén, en las que se muestran escenas de la población mapuche en un contexto de asimilación cultural. Una serie particularmente significativa dentro de esta sección retrata escenas y actividades de niños mapuche internados en la Escuela Granja Hogar Ceferino Namuncurá.

Otras imágenes de este periodo testimonian la pervivencia -especialmente en zonas rurales- de prácticas ceremoniales tradicionales, aunque realizadas con poca exposición pública debido al clima de discursos desvalorizadores vigentes en la época. Las fotografías de esta etapa fueron obtenidas en el Sistema Provincial de Archivos de la Provincia de Neuquén, en su mayoría con referencias de lugar y fecha, pero sin identificación de sus autores.

La tercera parte de la muestra refiere al último periodo, que caracterizamos como el momento de afirmación del pueblo mapuche. Esta sección tiene algunas características formales particulares: son fotos a color y en su gran mayoría captadas con cámaras digitales. Pero la particularidad más relevante es que corresponden a registros de los propios protagonistas, y que fueron seleccionadas según los momentos o acciones que ellos consideraron significativos.

25 Antonio Pozzo se incorporó en calidad de fotógrafo oficial en la columna al mando del Gral. Roca, en la expedición de 1879. Sus fotografías fueron compiladas en el «Álbum de vistas. Expedición al Río negro, abril a julio de 1879». Por su parte, los ingenieros Carlos Encina y Edgardo Moreno participaron entre 1882 y 1883 en una campaña de reconocimiento de nuevos territorios avanzando hacia el suroeste, por orden del mismo Julio A. Roca, ya en el cargo de presidente de la Nación. Sus fotos fueron publicadas como «Vistas fotográficas del Territorio Nacional del Limay y Neuquén. Tomos I y II». 


\section{Un recorrido visual. De la conquista a la afirmación del pueblo mapuche}

La composición de esa serie de fotografías abarcando los últimos 130 años de ocupación territorial y cultural, estuvo orientada por la reflexión acerca de los diversos modos de tratamiento de la alteridad, y su vinculación con contextos históricos y disputas políticas más amplias.

Dentro del régimen de elaboración simbólica de la nación y sus otros, dominante desde fines de siglo XIX hasta mediados del siglo XX, tanto la fotografía como el cine fueron mucho más que medios descriptivos de aquello que retrataban, ya que en sus producciones vehiculizaron determinadas maneras de ver, atravesadas por valoraciones negativas acerca de los modos de vida nativos, reproduciendo a menudo imaginarios metropolitanos de la alteridad previamente constituidos discursivamente.

La estrategia de representación visual de la campaña militar de 1879 lo muestra de manera patente, dado que contó con un fotógrafo profesional como Antonio Pozzo, experimentado en retratar a los sectores de poder y en inmortalizar reuniones científicas y acontecimientos modernizadores. Como fotógrafo oficial de la campaña, se propuso componer un registro del itinerario, de los expedicionarios, del hábitat y de los habitantes de aquellos espacios en vías de ser incorporados a la Nación. Aunque como sostiene Risso, ${ }^{26}$ las fotos de Pozzo excedieron el simple estatus de registro, y trascendieron con un «significativo poder de significar el poder», elaborando una representación celebratoria de esa etapa fundacional de la Argentina que sigue operando, aunque no sin discusiones, hasta el presente. ${ }^{27}$

Las fotos de las expediciones militares de la época muestran sistemáticamente espacios amplios y deshabitados. Las tomas panorámicas, con mucha presencia del horizonte, transmiten la extensión del espacio disponible para dominar, a la vez que la grandeza de la empresa en marcha. Esas capturas del paisaje patagónico tenían, no obstante, más el sentido de una constatación que el de un descubrimiento. Esas fotografías se remitían a una serie de discursos - a la vez que los reforzaban-que desde hacía tiempo

venían in-formando hegemónicamente a dicho espacio en términos de un desierto, es decir, un espacio vacío, abandonado, extenso, temible y desconocido, un no man's land, una tierra sin «hombres verdaderos»; configuración espacial a partir de la cual se negó la existencia indígena y se legitimó la ocupación e incorporación de esas tierras al Territorio Nacional... ${ }^{28}$

Por su parte, las imágenes que incluían sujetos, pueden agruparse en dos tipos: por un lado, las que mostraban escenas cuidadas en las que posaban jefes militares, formaciones de tropa disciplinada o columnas en marcha; y por otro lado, fotografías de indios sometidos, imágenes que atestiguaban el avance exitoso de la conquista (Figuras 1 a 5).

Figura 1.

Plaza de maniobras de los Cora-

ceros de Puán, 1879.

Fuente: Archivo General de la Nación. Documentos fotográficos. Inventario 291092. Foto: Antonio Pozzo.

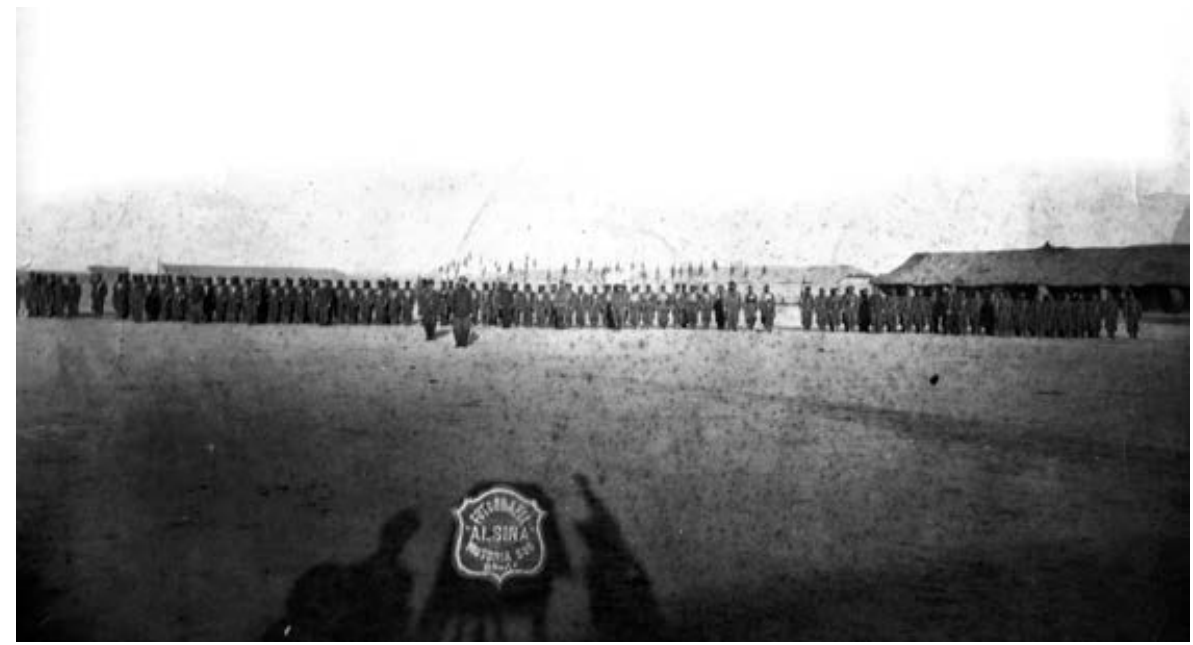

27 En este sentido sostiene el autor que «las fotografías de Pozzo pueden ser leídas, sin dudas, como cuestión de estado». Julio Risso, «Estado Nación, Conquista del Desierto», 4.

28 Risso, «Estado Nación, Conquista del Desierto», 5. 


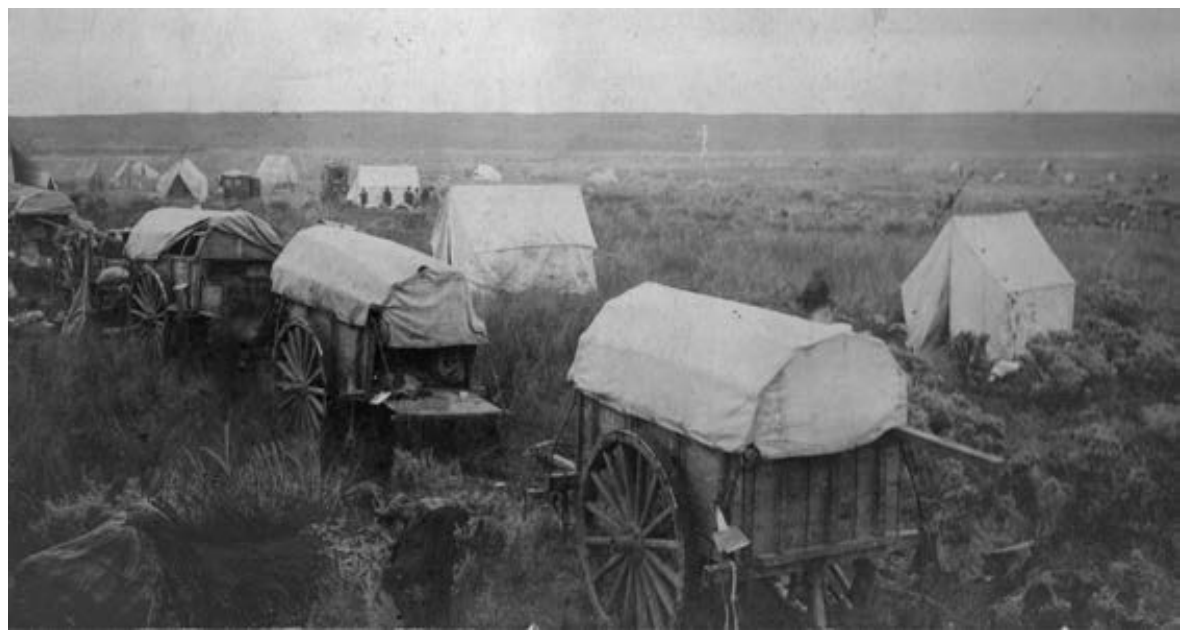

Figura 2.

Desplazamiento militar, 1878-1879. Fuente: Archivo General de la Nación. Documentos fotográficos. Inventario 146918. Foto: Antonio Pozzo.

Figura 3.

Ejército al mando del Gral. Roca en la ribera del Río Negro. Celebración del 25 de mayo de 1879. Fuente: Archivo General de la Nación. Documentos fotográficos. Inventario 146893. Foto: Antonio Pozzo.
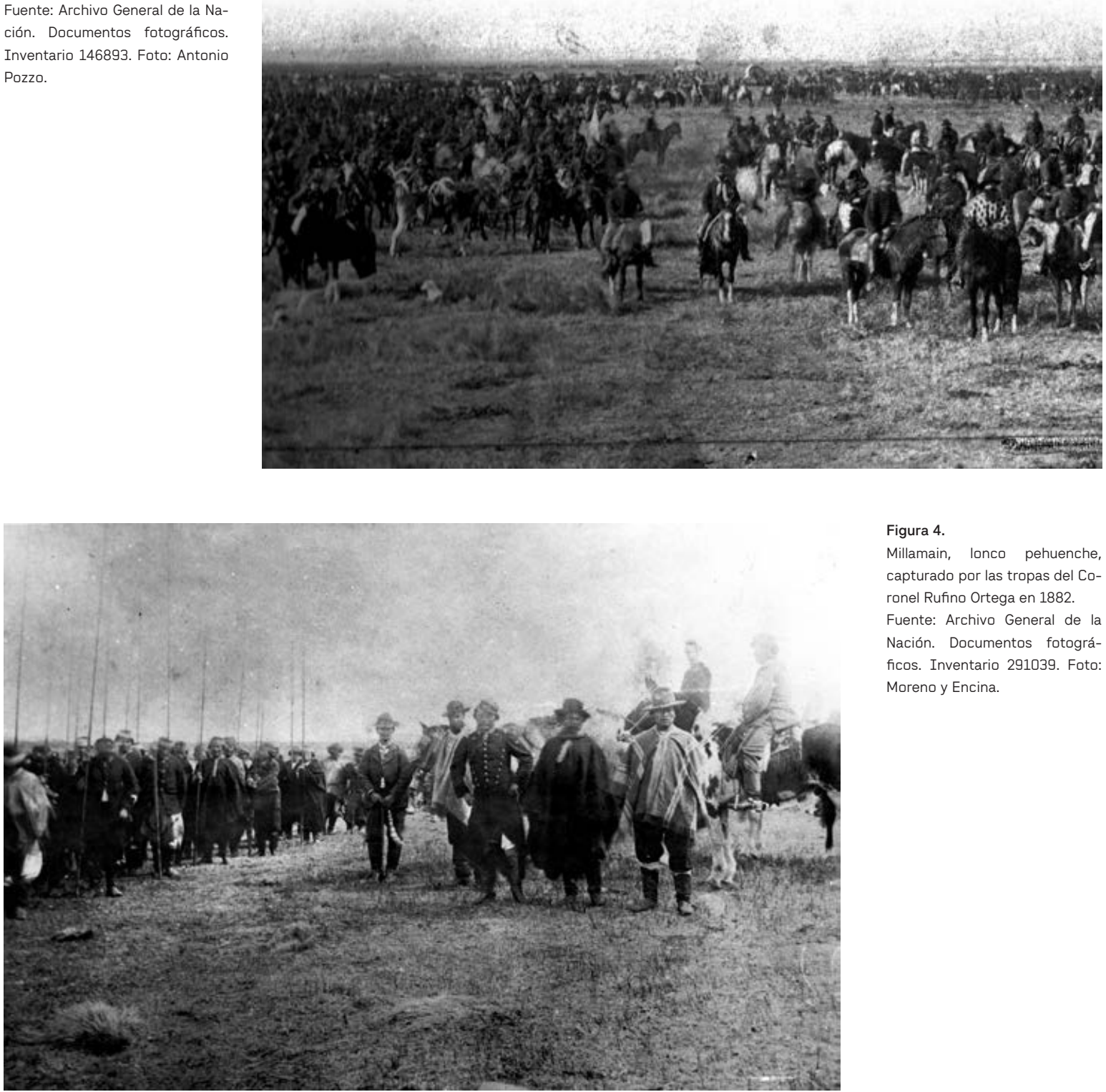

Figura 4.

Millamain, lonco pehuenche, capturado por las tropas del Coronel Rufino Ortega en 1882 Fuente: Archivo General de la Nación. Documentos fotográficos. Inventario 291039. Foto: Moreno y Encina. 


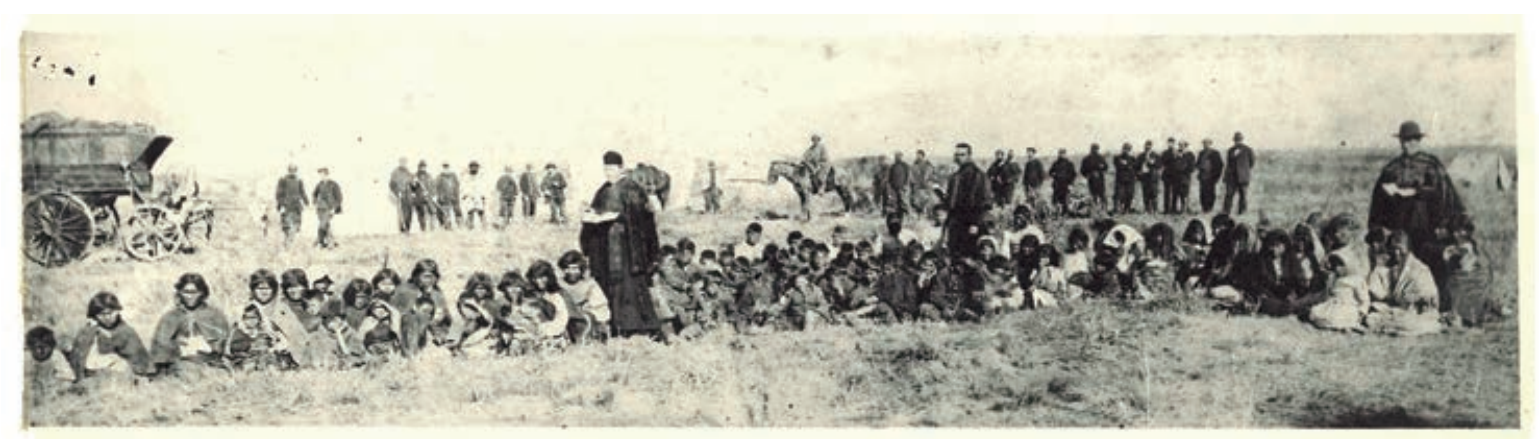

Figura 5 .

Doctrina por el Reverendo Espinoza, luego Arzobispo. Choele Choel, margen del Río Negro, 1879.

Foto: Antonio Pozzo.

Un rasgo a destacar es la presentación de los indígenas sometidos vestidos con uniforme militar (una práctica ya efectuada anteriormente por parte de los «indios amigos»). Su implementación durante y después de la campaña tiene una fuerte carga en tanto materialización de la imposición cultural, y más aún, de la aceptación por parte de los vencidos de los símbolos del conquistador. La foto de quien fuera el lonko (cacique) Manuel Namuncurá con el uniforme de coronel del Ejército argentino (Figura 6) resulta en este sentido especialmente impactante.

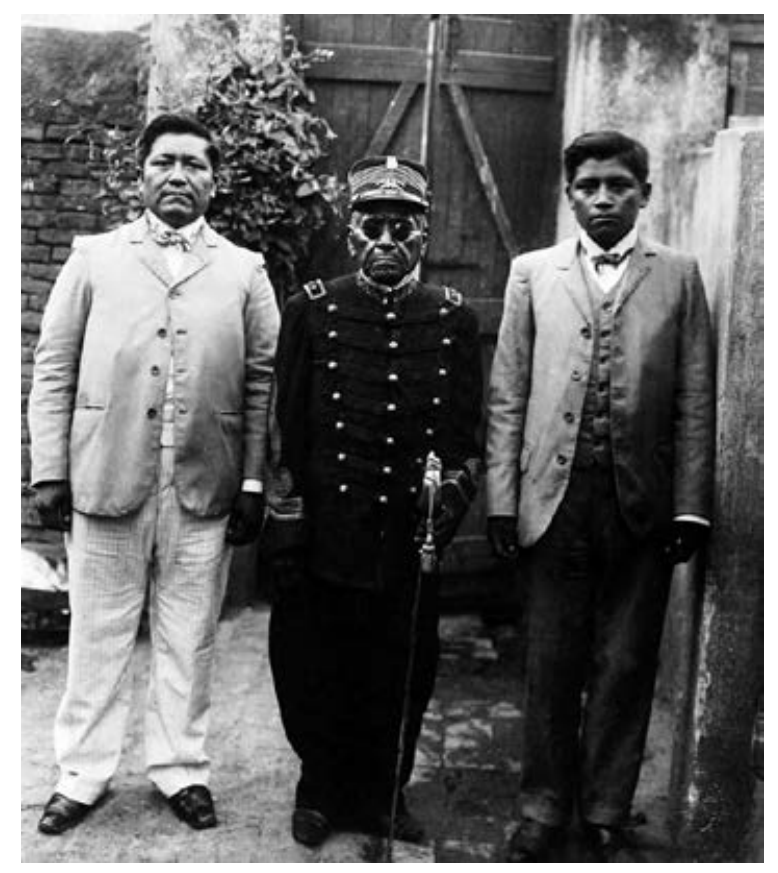

Figura 6.

Lonco Manuel Namuncurá con uniforme del Ejército Nacional junto a sus hijos Ceferino y Julián, c. 1903.

Fuente: Archivo General de la Nación. Documentos fotográficos. Inventario 94706.
Si bien en este trabajo no se profundizó en esa dirección, un análisis sistemático de los elementos simbólicos de la dominación, presentes en la producción fotográfica durante la conquista, evidenciaría claramente la dimensión política de estas imágenes y su papel legitimador. A modo de ejemplo baste mencionar dos fotos de Pozzo. Una de ellas, registra la celebración del 25 de mayo de 1879 — fecha patria por excelencia en la Argentina en conmemoración de la Revolución de mayo de 1810, inicio de la lucha independentista- en cercanías del río Negro, en Choele Choel. La celebración de ese día en ese lugar, y la fotografía que lo atestigua, constituyen la concreción de la toma de posesión por parte del Estado nacional de los territorios "ganados al indio» (Figura 3).

Por otro lado, la fotografía titulada «Doctrina por el Reverendo Espinoza...» (Figura 5) elabora simbólicamente el sometimiento de los indígenas, no sólo en términos físicos como lo sugiere el amontonamiento de sus cuerpos a ras del piso, sino también en términos espirituales a través de la religión, pieza clave de las políticas de imposición cultural. Es notable por otro lado, la puesta en escena en la que los religiosos, al igual que los indígenas y la fila de soldados que aparece en segunda línea, miran al frente, es decir, en dirección a la cámara.

Cabe recordar que la fotografía (y posteriormente el cine) también desempeñaron un papel estratégico en el proyecto evangelizador de los salesianos en la Patagonia. Un caso destacable es el film Tierras magallánicas de Alberto De Agostini, rodado en Tierra del Fuego entre 


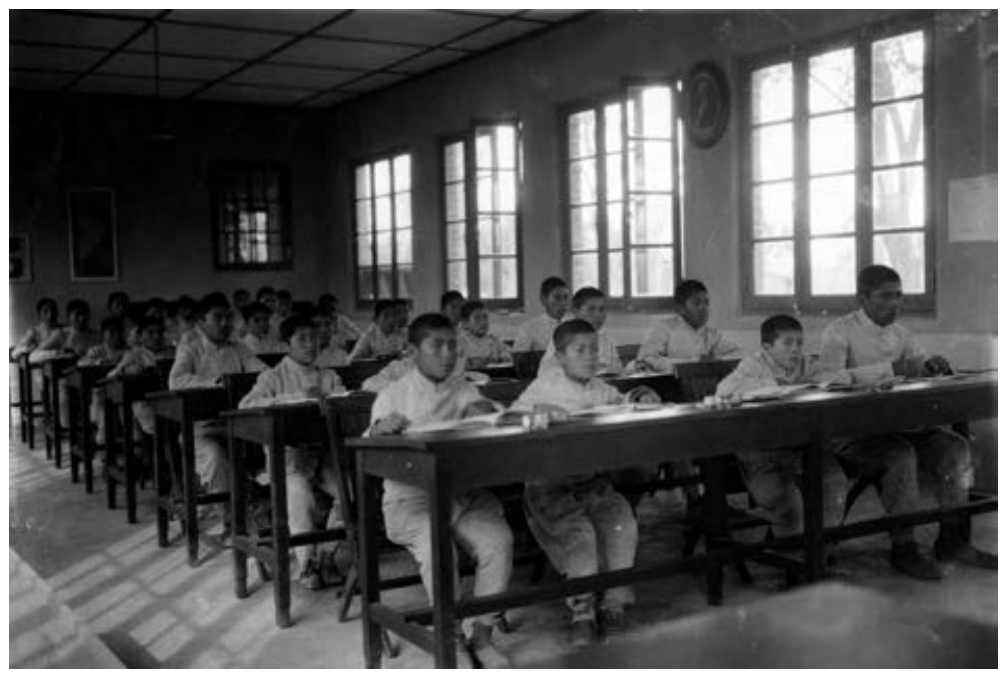

Figuras 7 y 8 .

Escuela granja hogar para niños indígenas Ceferino Namuncurá.

Fuente: Sistema Provincial de Archivos, Provincia de Neuquén.

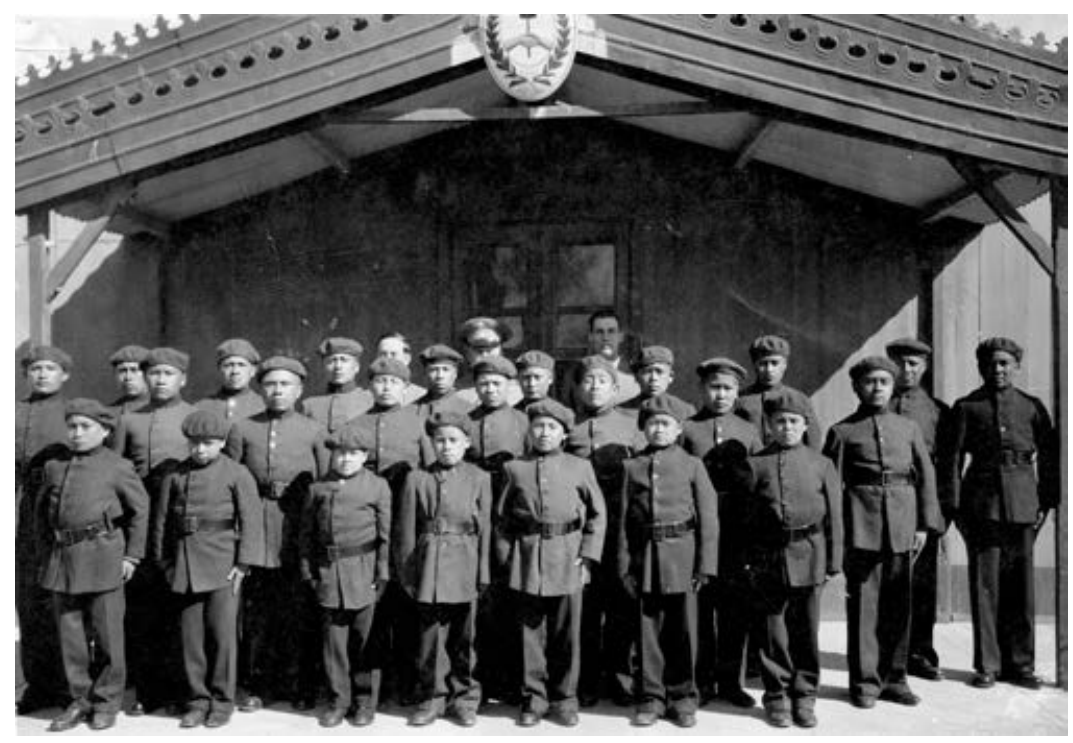

1915 y 1930. Además de mostrar a espectadores de distintas partes del mundo los variados entornos naturales del extremo sur del continente, la película presentaba un relato visual sobre la vida de los nativos y la obra llevada a cabo por las instituciones misioneras. El contraste entre la situación de grupos viviendo en la miseria según sus propias pautas, y la de individuos y familias integrados a la vida moderna en las misiones buscaba mostrar con aparente evidencia las ventajas civilizatorias de la obra salesiana. ${ }^{29}$

29 Scarzanella propone un interesante análisis sobre la relación entre «la fotografía misionera» y «la economía de la conversión» llevada a cabo a principios del siglo XX por los salesianos a modo de política cultural asimilacionista en los confines australes, territorios en los que las instituciones estatales tenían por entonces muy escasa presencia. Eugenia Scarzanella, Ni gringos ni indios.
Dentro del segundo periodo, caracterizado como etapa postconquista y que ocupó un lugar intermedio en la muestra, resulta relevante una serie de fotografías correspondientes a la Escuela Granja Hogar para niños indígenas Ceferino Namuncurá. En esas imágenes se observa, por un lado, una disposición de los cuerpos que deja entrever el sesgo disciplinario de la institución; desde la distribución en el espacio del aula según la clásica cuadrícula del sistema educativo moderno-occidental, hasta las escenas de formación en las que los cuerpos indígenas, debidamente uniformados, replicaban los modos de ordenamiento protocolar de las instituciones castrenses (Figuras 7 y 8 respectivamente).

Inmigración, criminalidad y racismo en la Argentina, 1890-1940 (Bernal: Universidad Nacional de Quilmes, 2015). 


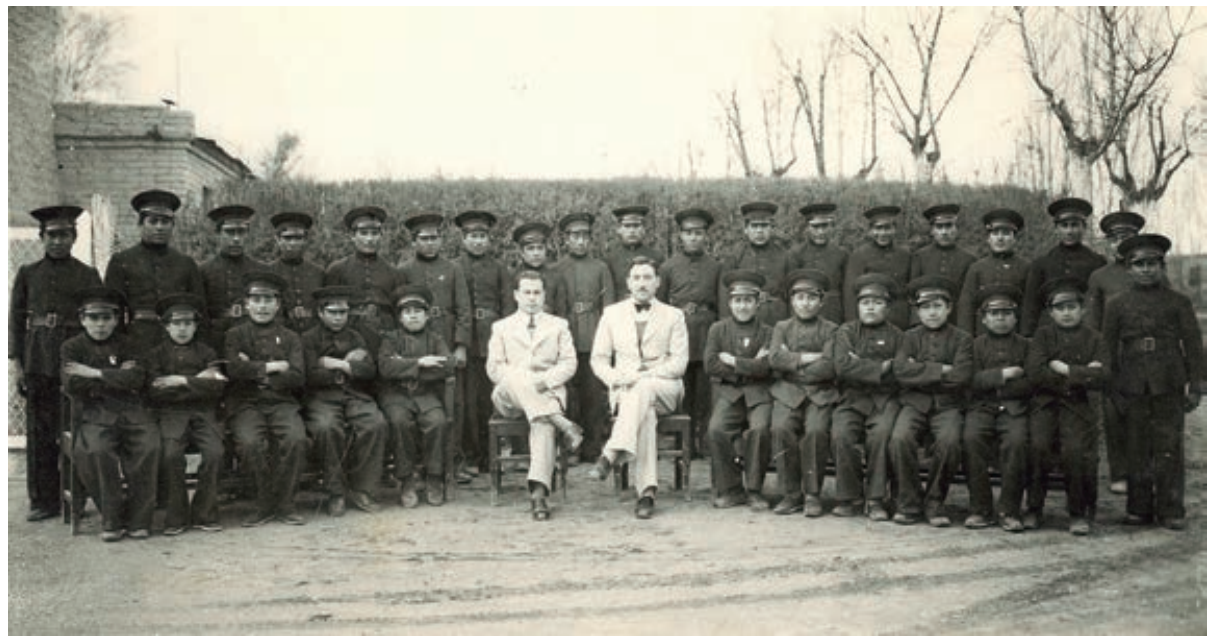

Figura 9.

Escuela granja hogar para niños indígenas Ceferino Namuncurá. Fuente: Sistema Provincial de Archivos, Provincia de Neuquén.

\section{Figura 10.}

Escuela granja hogar para niños indígenas Ceferino Namuncurá. Fuente: Sistema Provincial de Archivos, Provincia de Neuquén.

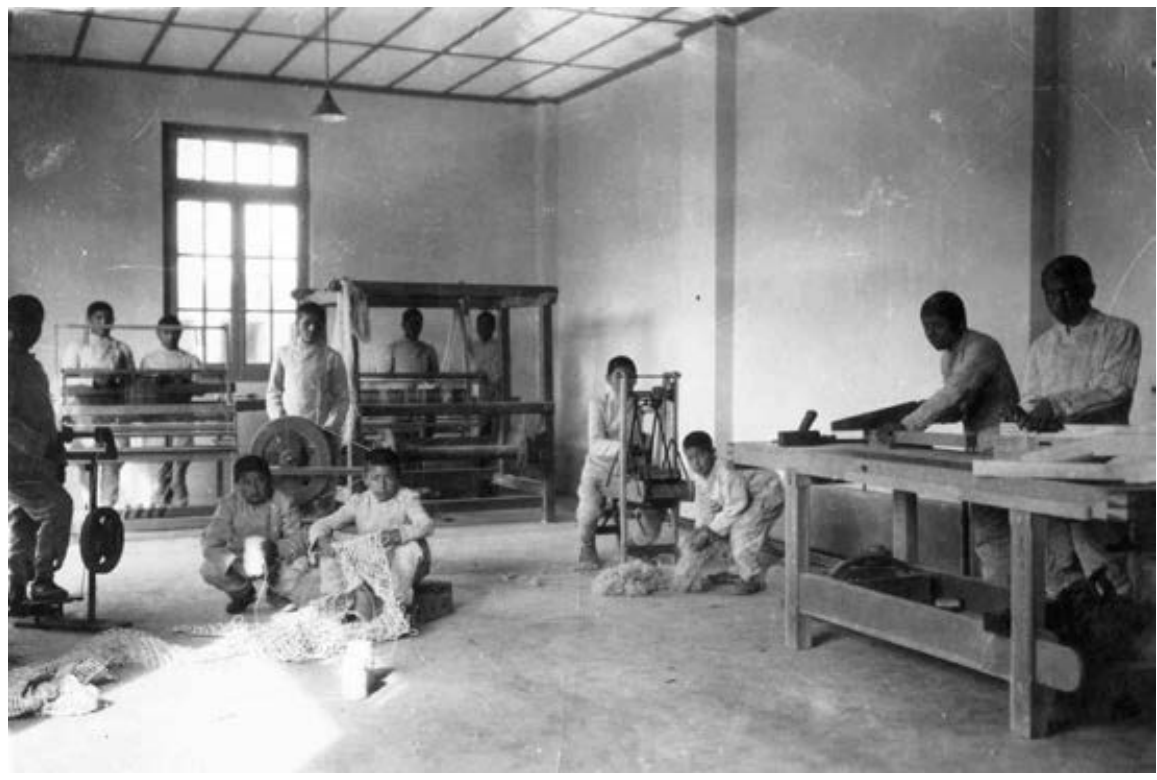

Por su parte, en la Figura 9 se deja ver de manera notable la estructura de poder y jerarquía cultural existente dentro de la escuela-internado; retrato de una escenificación centrada en la figura clara, prolija y segura de los maestros, secundados por una oscura multitud de niños indígenas vestidos como pequeños gendarmes, con uniformes prestados. ${ }^{30}$

Por otra parte, la obra civilizadora de la institución educativa salta a primer plano en las actividades de aula así como en el aprendizaje de oficios en

30 Las apelaciones a la disciplina militar eran comunes en la escuela, como se puede observar también en la Figura 8. Según consta en los informes anuales del director de la escuela, los uniformes para «ocasiones de gala» eran donados por Gendarmería Nacional, en la medida en que quedaban fuera de uso. Memorias anuales de la Gobernación del Neuquén de 1935 a 1942. Sistema Provincial de Archivos, Provincia de Neuquén, Argentina. el taller (Figuras 7 y 10). En este sentido, lo que la escuela buscaba mostrar a través de las visitas, los informes escritos y las fotografías, más que simplemente a niños indígenas, era a niños indígenas ganados por y para la civilización.

Tanto en la etapa de conquista militar como en la de asimilación, los recursos de representación positiva de la cultura occidental (en rigor, la única considerada propiamente cultura) y de desvalorización de los modos de vida otros, tendieron a conformar un «sentido común visual» ${ }^{31}$ que confirmaba los discursos dominantes acerca de las diferencias y las relaciones de jerarquía entre ellas. De este modo, la reproducción técnica y la circulación de esas

\footnotetext{
31 Sergio Caggiano, El sentido común visual. Disputas en torno a género, raza y clase en imágenes de circulación pública (Buenos Aires: Miño y Dávila, 2012), 53.
} 


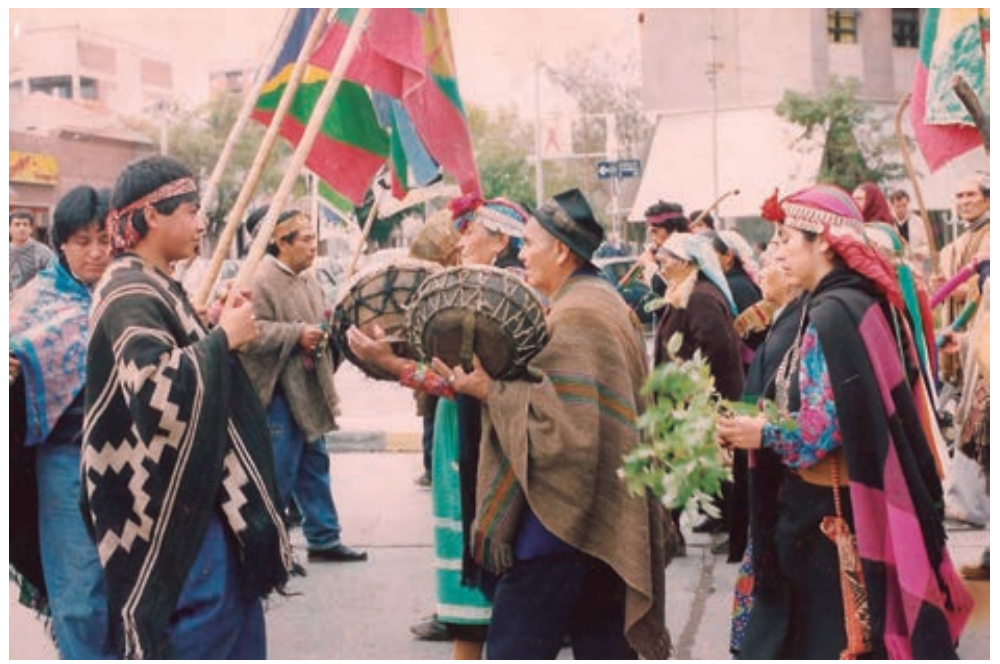

Figura 11.

Reencuentro del Pueblo Mapuche de gulumapu (tierra del oeste / Chile) y puelmapu (tierra del este / Argentina). Ciudad de Neuquén, 1991.

Foto: Confederación Mapuche de Neuquén. imágenes contribuyó a cimentar un particular imaginario sobre la alteridad, mostrando como autoevidente - y de ese modo legitimando - la relación de superioridad y dominio del modelo cultural de la nación respecto de sus otros internos. ${ }^{32}$

Un punto de inflexión se produce en la tercera sección de la muestra, haciéndose eco e incorporando al recorrido visual propuesto, el cambio en el modo de tratamiento de la alteridad que se esboza en el último tramo del siglo XX. Se trata del salto a la escena - aunque no libre de objeciones y obstáculos - de una visión crítica respecto de los relatos anteriores acerca de las diferencias, y más importante aún, de una práctica de auto-representación indígena centrada en su afirmación cultural como pueblo. Un salto que, evidentemente, desestabiliza el régimen de jerarquización cultural y de representación visual tradicional que se refleja en toda la primera parte de la muestra, al producir una ampliación a la vez que un desplazamiento en ese corpus documental, con la introducción de fotos que muestran un modo diferente de significar.

A diferencia de las etapas anteriores, no se trata ya de indígenas fotografiados por blancos, sino de acciones de auto-representación y definición de qué y cómo mostrar(se). Según argumenta Caggiano:

32 El concepto «otros internos» es utilizado por Briones al analizar las políticas históricas de incorporación subordinada de los pueblos indígenas en las lógicas del sistema capitalista y del Estado nación. Claudia Briones, La alteridad del Cuarto Mundo. Una deconstrucción antropológica de la diferencia (Buenos Aires: Ed. del Sol, 1998). El tema también es abordado por Rita Segato en La Nación y sus otros (Buenos Aires: Ed. Prometeo, 2007).
Tenemos así, de un lado, las fotos de finales del siglo XIX y primeros años del XX o bien las fotos actuales reproduciendo el modelo de las fotos clásicas de tipos raciales o étnicos, los dibujos infantiles de los manuales escolares que, sin fuerza testimonial, evocan la época en que «había» indios, y otros mecanismos de fijación de lo indígena en un tiempo remoto. De otro lado, el presente y el futuro en las imágenes de niños y niñas, en la modernidad de las nuevas tecnologías como parte de la cotidianeidad indígena, en la vigencia de las celebraciones rituales captadas con una cámara digital. Entre un conjunto de imágenes y el otro, una clara divergencia en la construcción y adjudicación de referencias temporales para los pueblos originarios. ${ }^{33}$

Las fotos incluidas en la última sección de la muestra refieren a los momentos significativos para el pueblo mapuche en Neuquén; de este modo podemos decir que reflejan los diversos pasos de su proceso de reorganización y afirmación político-cultural. La serie se inicia con dos imágenes de un acontecimiento decisivo como fue el reencuentro del pueblo mapuche del este y del oeste de la cordillera, los actuales territorios de Argentina y Chile, reivindicando su unidad como pueblo preexistente a los estados nacionales en que fueron incluidos por la fuerza. Ese encuentro ocurrió en la coyuntura de la celebración del quinto centenario del descubrimiento de América, ocasión en que se organizaron contrafestejos y movimientos de protesta en todo el continente (Figuras 11 y 12).

33 Caggiano, El sentido común visual, 215. 


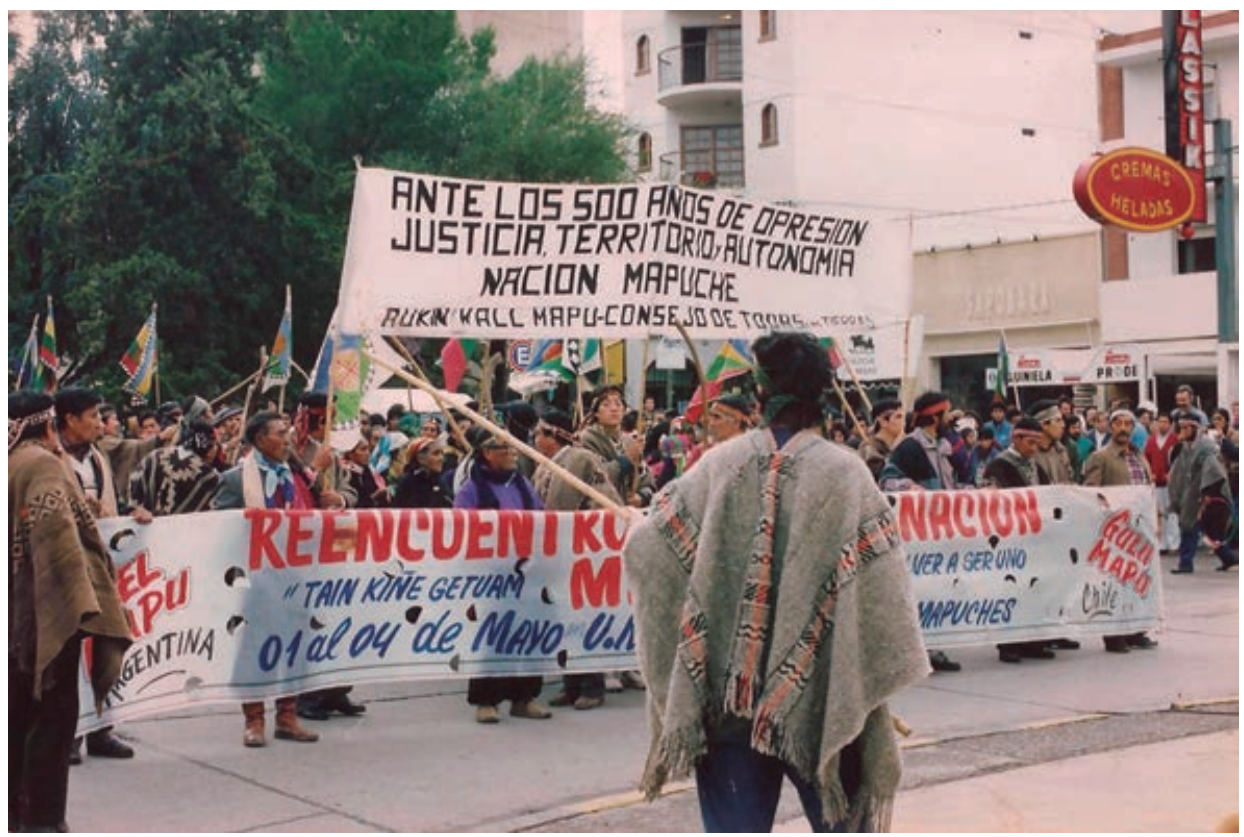

Figura 12.

Manifestación en ocasión del quinto centenario del descubrimiento de América. Ciudad de Neuquén, 1992.

Foto: Confederación Mapuche de Neuquén.

La selección realizada en conjunto con representantes de las organizaciones mapuche, sobre un importante caudal de fotos tomadas por ellos mismos, especialmente en años recientes, incluyó acontecimientos de distinto tenor: movilizaciones, acciones de recuperación territorial, ceremonias, actividades culturales y de educación autónoma, registro y denuncia de contaminación, entre otros (Figuras 13 a 16).

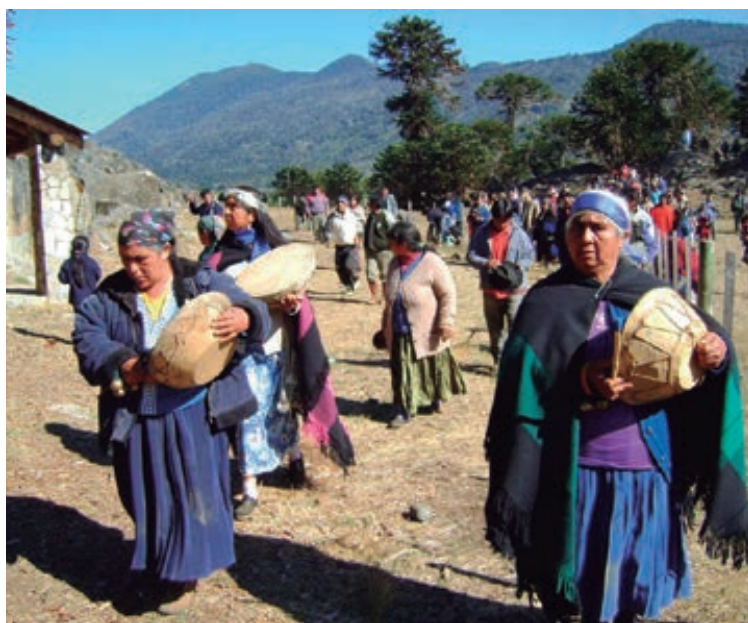

Figura 13.

Salida de ceremonia de reafirmación territorial en Piedra Pintada. Aluminé, 2009. Foto: Ailín Wenaywen.

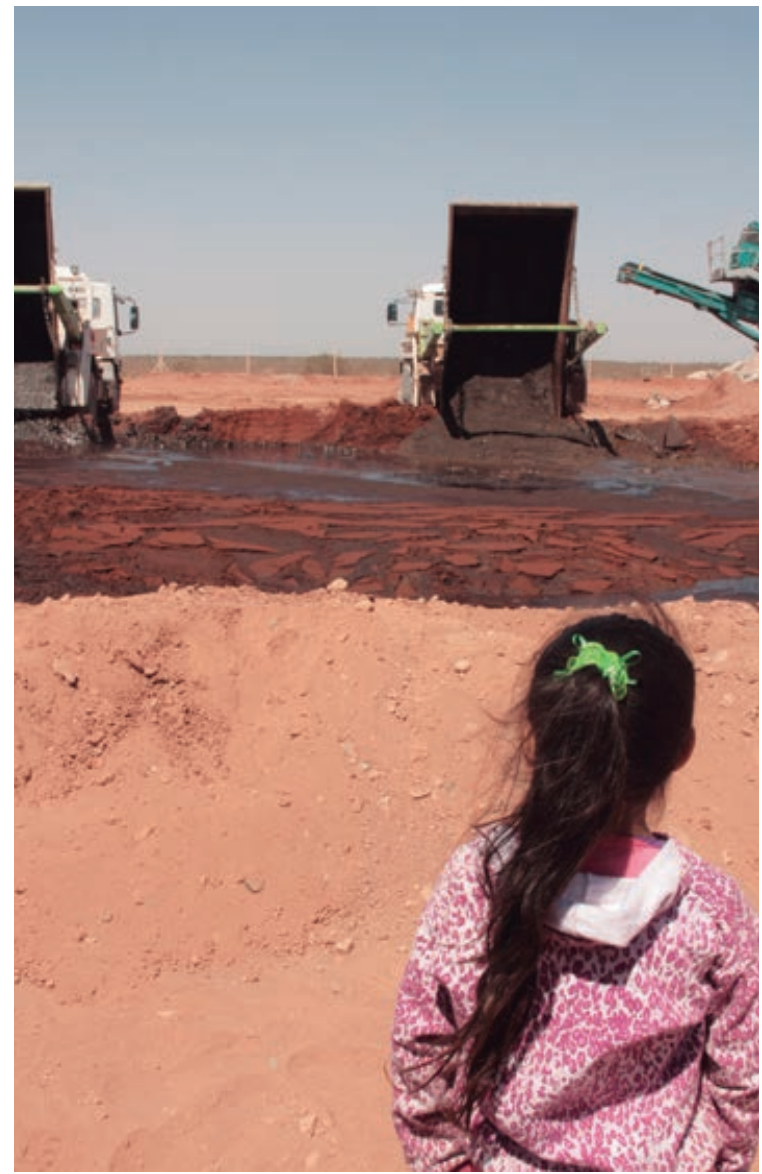

Figura 14.

Comunidad Kaxipayiñ. Desechos de petróleo crudo por explotación petrolífera. Mari Menuco, Prov. de Neuquén, 2011. Foto: Kvrvf Nawel. 


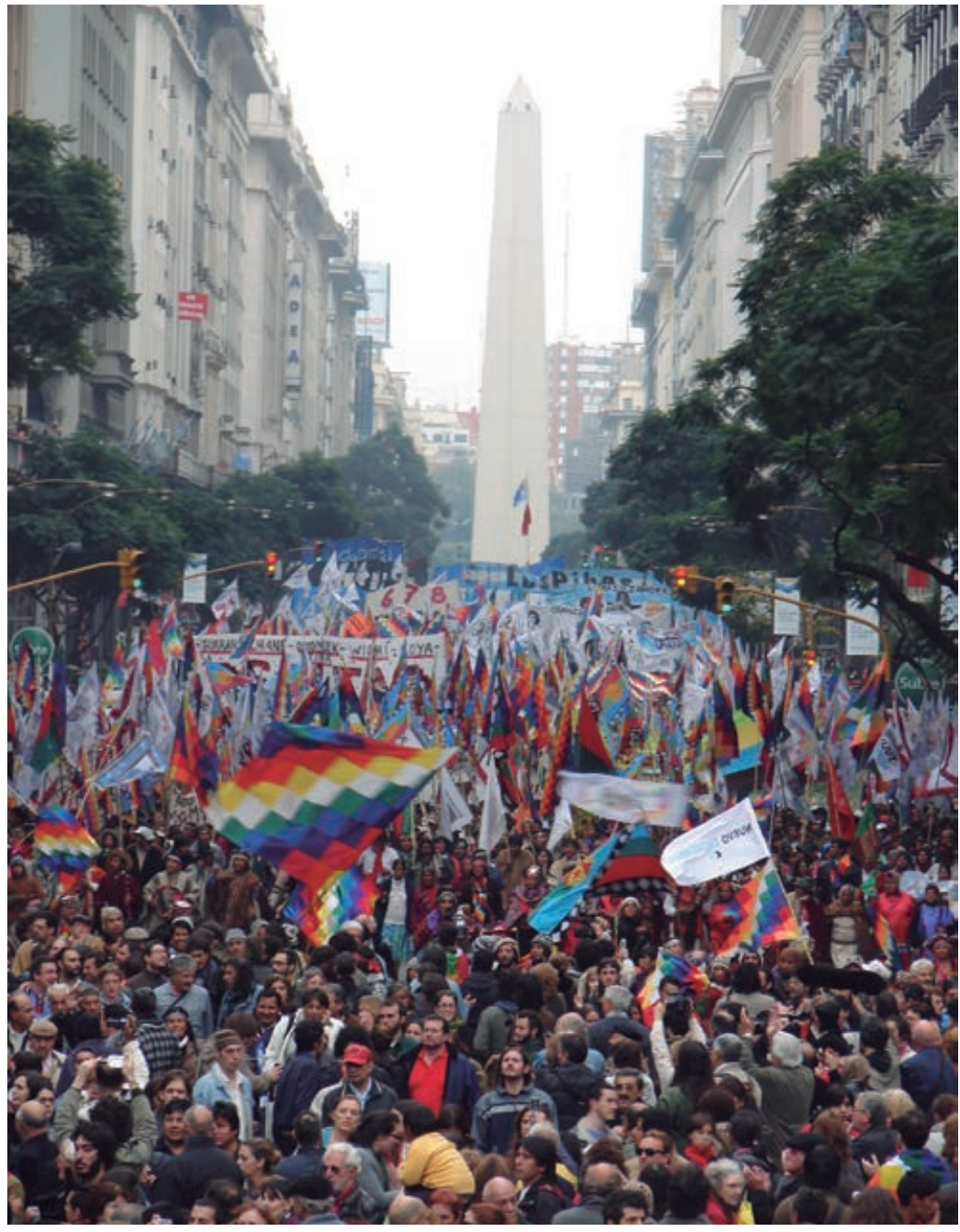

Figura 15.

Marcha de los Pueblos Originarios a Buenos Aires. Acto en Plaza de Mayo. Ciudad de Buenos Aires, 2010

Foto: Newen Piciñam.

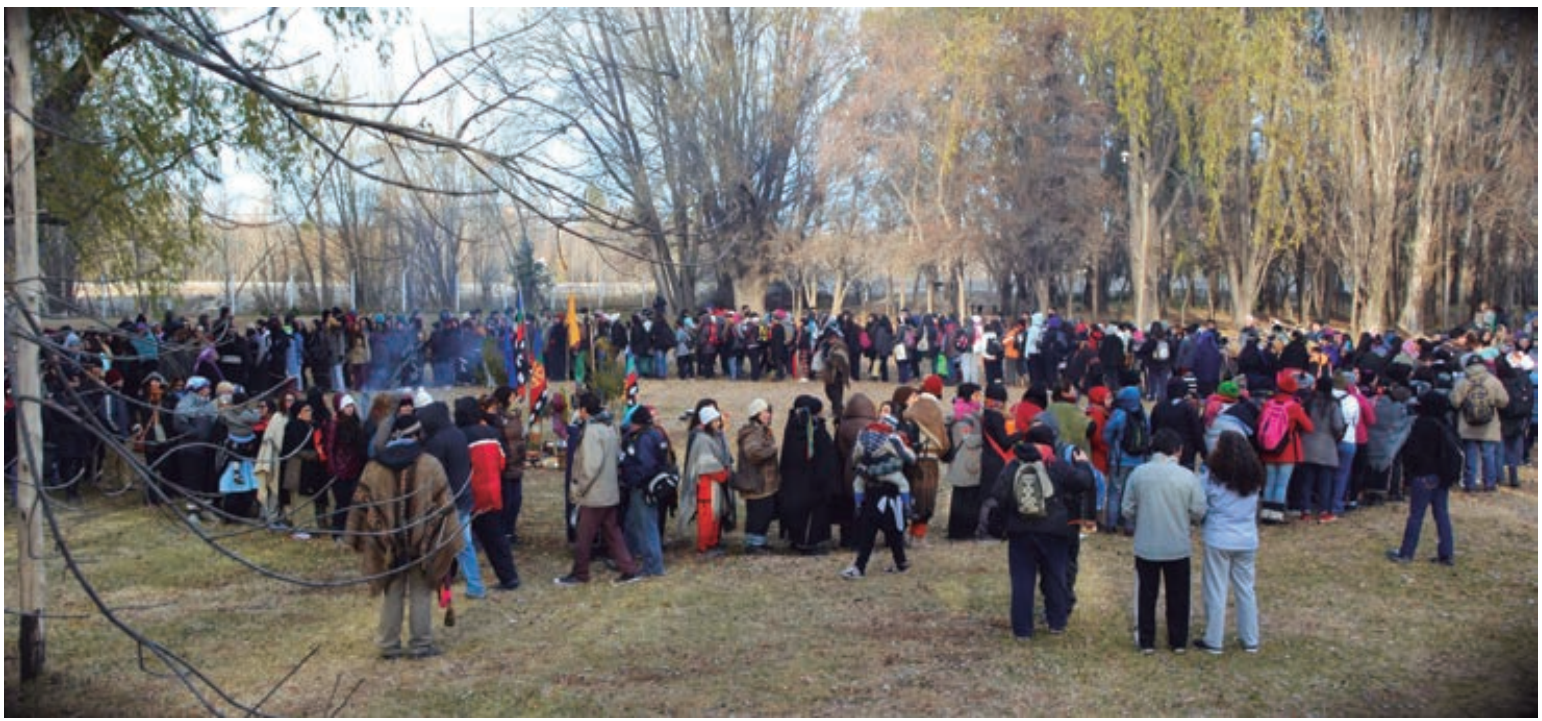

Figura 16.

Celebración del Wiñoy Xipantv (vuelta del sol). Ciudad de Neuquén, 2015. Foto: Sol García. 
Retomando una vez más conceptos de Caggiano,

La cultura visual es uno de los espacios en que tiene lugar tanto la producción y reproducción de relaciones de poder y de desigualdad, como también de formas de resistencia o alternatividad. El juego de caracterizaciones, visualizaciones y ocultamientos, exclusiones e inclusiones, jerarquías y sesgos, organiza las relaciones y las posiciones sociales. [...] No obstante, mientras algunos actores buscan estabilizar dicho juego y, de ese modo, naturalizar esas relaciones y posiciones con sus diferencias y desigualdades, otros actores pueden responder o desatender estas formas de visualización y ocultamiento, desestabilizarlas al promover otras. ${ }^{34}$

En el contexto norpatagónico existen actualmente equipos de comunicadores mapuche y multitud de fotógrafos y videastas amateur, que intervienen en el plano de las representaciones sociales, cuestionando las configuraciones de sentido tradicionales a la vez que promoviendo otras, desde otros criterios de valoración. Resulta interesante pensar en el uso de las nuevas tecnologías disponibles (en particular los dispositivos audiovisuales y de comunicación) en convergencia y aun potenciando las políticas de afirmación cultural. La actualización es un síntoma de vitalidad de toda cultura, y un desafío para los pueblos originarios, generalmente conminados a mantenerse anclados a sus orígenes so pena de ser denunciados por inautenticidad. Por lo pronto, ante el evidente callejón sin salida al que nos conduce el modo de estar en el mundo centrado en las matrices de desarrollo y progreso heredados de la modernidad, se hace necesaria la invención de nuevos imaginarios que estén más en sintonía con el «buen vivir», y como se sabe, los imaginarios están hechos — también — de imágenes.

\section{Bibliografía}

\section{Fuentes primarias}

Archivo General de la Nación (AGN), Buenos Aires, Argentina. Sección de documentación fotográfica.
Sistema Provincial de Archivos, Provincia del Neuquén, Argentina. Fototeca: carpetas «Aborígenes» $\mathrm{y}$ «Campaña al desierto».

Sistema Provincial de Archivos, Provincia del Neuquén, Argentina. Memorias anuales de la Gobernación del Neuquén de 1935 a 1942.

\section{Fuentes secundarias}

Alimonda, Héctor y Juan Ferguson. «La producción del desierto. Las imágenes de la campaña del Ejército Argentino contra los indios, 1879». Revista Chilena de Antropología Visual 4 (2004). http://www. antropologiavisual.cl/alimonda_\&_ferguson.htm

Alvarado, Margarita, Pedro Mege Rosso y Christian Báez Allende. Mapuche: fotografías siglos XIX y XX. Construcción y montaje de un imaginario. Santiago de Chile: Pehuén Editores, 2001. Disponible en Memoria Chilena, Biblioteca Nacional de Chile. http://www.memoriachilena. cl/602/w3-article-9632.html

Báez, Chistian y Peter Mason. Zoológicos humanos. Fotografías de fueguinos y mapuche en el Jardin d'Acclimatation de París, siglo XIX. Santiago de Chile: Pehuén Editores, 2006.

Barthes, Roland. La cámara lúcida. Nota sobre la fotografía. Barcelona: Paidós, 1989.

Bennett, Tony. «The Exhibitionary Complex». En The Birth of the Museum. History, Theory, Politics, editado por Tony Bennett, 59-86. Routledge: London, 1995.

Briones, Claudia. «Formaciones de alteridad: contextos globales, procesos nacionales y provinciales». En Cartografías argentinas. Politicas indigenistas y formaciones provinciales de alteridad, editado por Claudia Briones, 11-43. Buenos Aires: Antropofagia, 2005.

Briones, Claudia. La alteridad del Cuarto Mundo. Una deconstrucción antropológica de la diferencia. Buenos Aires: Ed. del Sol, 1998.

34 Caggiano, El sentido común visual, 52-53. 
Caggiano, Sergio. El sentido común visual. Disputas en torno a género, raza y clase en imágenes de circulación pública. Buenos Aires: Miño y Dávila, 2012.

Castro-Gómez, Santiago. "Ciencias Sociales, violencia epistémica y el problema de la "invención del otro"». En La colonialidad del saber: etnocentrismo y ciencias sociales, compilado por Edgardo Lander, 145-161. Caracas: Clacso, 2000.

Cortés Rocca, Paula. El tiempo de la máquina. Retratos, paisajes y otras imágenes de la nación. Buenos Aires: Ed. Colihue, 2011.

Foucault, Michel. Defender la Sociedad. Curso 19751976. Buenos Aires: FCE, 2010.

Giordano, Mariana. «Nación e identidad en los imaginarios visuales de la Argentina. Siglos XIX y $\mathrm{XX}$ ».ARBOR Ciencia, Pensamiento y Cultura, n. ${ }^{\circ}$ 740 (noviembre-diciembre 2009): 1283-1298.

Kriscautzky, Xavier. Desmemoria de la Esperanza. Buenos Aires: Ministerio de Educación de la Nación, 2007.

Lois, Carla. «Técnica, política y deseo territorial en la cartografía oficial de la Argentina (18521941)». Scripta nova. Revista electrónica de geografía y ciencias sociales X, n. 218 (2006).

Martínez, Alejandro y Liliana Tamagno. «La naturalización de la violencia: Un análisis de fotografías antropométricas de principios del siglo XX». Cuadernos de Antropología Social, n. 24 (2006): 93-112.

Naranjo, Juan. Fotografía, antropología y colonialismo (1845-2006). Barcelona: Editorial Gustavo Gili, 2006.

Penhos, Marta. «Frente y perfil. Una indagación acerca de la fotografía en las prácticas antropológicas y criminológicas en Argentina a fines del siglo XIX y principios del XX». En Arte y Antropología en Argentina, 15-64. Buenos Aires: Fundación Espigas, 2005.

Risso, Julio. «Estado Nación, Conquista del Desierto e imágenes de(1) nos-otros. Una propuesta de lectura sobre (re)presentaciones identitarias en Argentina». Jornadas Internacionales de Problemas Latinoamericanos, Universidad Nacional de Cuyo, Mendoza, Argentina, 2012.

Sánchez, Fernando. «El Internado para niños indígenas Ceferino Namuncurá. Un caso paradigmático de educación asimilacionista». Construcción de espacios interculturales, compilado por Raúl Díaz y Graciela Alonso, 183-193. Buenos Aires - Madrid: Ed. Miño y Dávila, 2004.

Sánchez, Fernando. «Inventarios de la civilización. Geopolíticas del saber y exhibiciones zooantropológicas en la construcción del mundo moderno colonial». Revista Chilena de Antropología Visual, n. 22 (2013): 46-67. http://www.rchav. cl/2013_22_art02_sanchez.html

Scarzanella, Eugenia. Ni gringos ni indios. Inmigración, criminalidad y racismo en la Argentina, 1890-1940. Bernal: Universidad Nacional de Quilmes, 2015.

Segato, Rita. La Nación y sus otros. Buenos Aires: Ed. Prometeo, 2007.

Tell, Verónica. «La Toma del Desierto. Sobre la auto-referencialidad fotográfica». En Actas del I Congreso Internacional de Teoría e Historia de las Artes/LX Jornadas del CALA «Poderes de la Imagen». Buenos Aires, CAIA, 2003 (CD-ROM).

Yujnovsky, Ines. «La conquista visual del país de los araucanos (1879-1881)». Takwá, n. 14 (2008). http://www.publicaciones.cucsh.udg.mx/ppe$\mathrm{riod} /$ takwa/volumenes/tak14.htm

- Recibido: 23 de febrero de 2017

Aprobado: 17 de octubre de 2017

Disponible en línea: 31 de diciembre de 2017

\section{Cómo citar este artículo}

Sánchez, Fernando M. «La construcción visual de la nación y sus otros. Imágenes y alteridades en la $\mathrm{Pa}$ tagonia Argentina». Memoria y Sociedad 21, n. 43 (2017): 86-103. https://doi.org/10.11144/Javeriana. mys21-43.cvno 